\title{
Patterns of Technological Pedagogical and Content Knowledge in Preservice-Teachers' Literacy Lesson Planning
}

\author{
Poonam Arya ${ }^{1}$, Tanya Christ ${ }^{2} \&$ Wen $\mathrm{Wu}^{3}$ \\ ${ }^{1}$ College of Education, Wayne State University, Detroit, MI, USA \\ ${ }^{2}$ School of Education and Human Services, Oakland University, Rochester, MI, USA \\ ${ }^{3}$ Guizhou University, China \\ Correspondence: Poonam Arya, 261 Education Building, Gullen Mall, Detroit, MI 48202, USA. E-mail: \\ parya@wayne.edu
}

Received: June 8, 2020 Accepted: July 11, 2020 Online Published: July 15, 2020

doi:10.5539/jel.v9n5p1 URL: https://doi.org/10.5539/jel.v9n5p1

\begin{abstract}
This study explored the patterns of Technological Pedagogical and Content Knowledge (TPACK) in 45 preservice teachers' literacy lesson plans that integrated digital texts or tools. A priori coding and content analysis were used to identify preservice teachers' demonstrations of combinations of TPACK constructs. Findings indicated that preservice teachers demonstrated TPACK (41\%) and combined Technological Content Knowledge and Pedagogical Content Knowledge most frequently (42\%), Pedagogical Content Knowledge less frequently (13\%), and other patterns rarely, combined Technological Content Knowledge and Technological Pedagogical Knowledge (1\%), Technological Content Knowledge (1\%), Technological Pedagogical Knowledge $(0 \%)$ and combined Pedagogical Content Knowledge and Technological Pedagogical Knowledge (0\%). This study cohered with previous research that found just under half of teachers demonstrated TPACK. However, it differed from previous studies that did not show patterns of Pedagogical Content Knowledge but Technological Pedagogical Knowledge, as our data showed Pedagogical Content Knowledge but not Technological Pedagogical Knowledge. Finally, it extended previous research by identifying patterns of literacy preservice teachers' demonstrations of TPACK in their elementary literacy lesson plans. It also demonstrated new ways of combining TPACK constructs (i.e., Technological Content Knowledge and Pedagogical Content Knowledge, Technological Content Knowledge and Technological Pedagogical Knowledge, and Pedagogical Content Knowledge and Technological Pedagogical Knowledge), which when used to code the data resulted in a more comprehensive definition of TPACK. Only $2 \%$ of the lesson plans did not demonstrate any of the combinations.
\end{abstract}

Keywords: lesson plan, literacy, preservice teacher, teacher preparation, Technological Pedagogical and Content Knowledge

\section{Introduction}

New literacy standards include the integration of digital texts and tools (CCSS, 2010; IRA, 2009; NCTE, 2008). To do this successfully, teachers must not only have knowledge about technologies and how to use them, but also knowledge about pedagogy and content. The Technological Pedagogical and Content Knowledge Framework (TPACK) integrates these areas and provides a framework for analyzing the extent and quality of teachers' integration of these (Koehler \& Mishra, 2009). While other frameworks explore teachers' instruction they do not substantively address technology integration with other aspects of pedagogy. For example, the Danielson Framework for Teaching addresses planning and preparation, classroom environment, instruction, and professional responsibilities (https://danielsongroup.org/framework). While these could include technology integration, it is not an explicit component. Likewise, the 5 Dimensions of Teaching and Learning Framework addresses standards, learning target and teaching points, intellectual work, engagement strategies, and talk (http://info.k-12leadership.org/5-dimensions-of-teaching-and-learning). This framework also does not address technology integration as a specific component of pedagogy. The Substitution Augmentation Modification and Redefinition Framework (Puentedura, 2010) does explicitly focus on how teachers integrate technology and how it compares to teaching without technology—e.g., substituting, augmenting, modifying, or redefining practices as compared to using paper texts or tools. This framework, however, does not explicitly consider teachers pedagogical or content knowledge, which we believe are critical to evaluating technology integration in lessons 
beyond the effectiveness of the technology itself. For example, a teacher might have a redefined use of a technological tool, but it may not address the content objective. Thus, for this study we adopted the TPACK Framework.

Within the existing body of research on TPACK, researchers have underscored the importance of considering content-area specific technology integration (Dexter, Doering, \& Riedel, 2006; Hughes \& Scharber, 2008; Sprague, 2004). However, only a handful of studies have focused on teachers' planning or application of TPACK specifically in literacy lessons (Boschman, McKinney, \& Voogt, 2015; Hutchison \& Colwell, 2016; Laster et al., 2016; Steckel, Shinas, \& Vaerenewyck, 2015). Most of the research on teachers' use of TPACK is situated (a) across disciplines, such as in elementary education (Finger \& Finger, 2013; Graham, Borup, \& Smith, 2012; Liu, 2013) or secondary education (Hofer \& Grandgenett, 2012), (b) in specific content areas such as foreign language (Wang, 2016; Zhang, 2019), science (Maeng, Mulvey, Smetna, \& Bell, 2013), math (Niess, 2009; Ozgun-Koca, Meagher, \& Edwards, 2011), or English (Hughes \& Scharber, 2008), or (c) in a particular education context, such as special education (Anderson, Griffith, \& Crawford, 2017). Further, studies of teacher's use of TPACK in literacy lessons often adopt TPACK as their theoretical framework, but rarely apply the constructs from the TPACK Framework to code their data (Boche, 2019; Hutchison \& Colwell, 2016; Laster et al., 2016; Steckel et al., 2015). Thus, while they discuss how their findings align with the TPACK Framework, they are not able to discuss to what extent specific TPACK constructs are represented in their data. Only Boschman and colleagues' (2015) explored how teachers demonstrated TPACK constructs during their small group discussions about literacy instructional design, and this study included just six teachers.

To extend existing research, we investigate how a greater number of preservice teachers demonstrate TPACK constructs in their literacy lesson planning. Particularly, we focus on how preservice teachers demonstrate different combinations of TPACK constructs: Technological Content Knowledge, Technological Pedagogical Knowledge, Pedagogical Content Knowledge, and TPACK (see Figure 1). This will allow us to better understand their integration successes and need for further development. Thus, our research is guided by the following question: What combinations of TPACK constructs do preservice teachers demonstrate through their literacy lesson planning, and to what extent do they demonstrate each of these combinations of constructs?

\section{TPACK: Theoretical Constructs}

Koehler and Mishra (2009) offer a framework for integrating digital texts and tools that considers Technological, Pedagogical, and Content Knowledge (i.e., TPACK). Technological Knowledge addresses how we use "technology for information processing, communication, and problem solving." Pedagogical Knowledge addresses "the processes and practices or methods of teaching and learning." Content Knowledge addresses "the subject matter to be learned or taught" (pp. 63-64). The framework presents the complex relationships among the three core constructs and how these influence teachers' decisions for effective technology integration in their teaching (Mishra \& Koehler, 2006; Thompson \& Mishra, 2007-2008; see Figure 1).

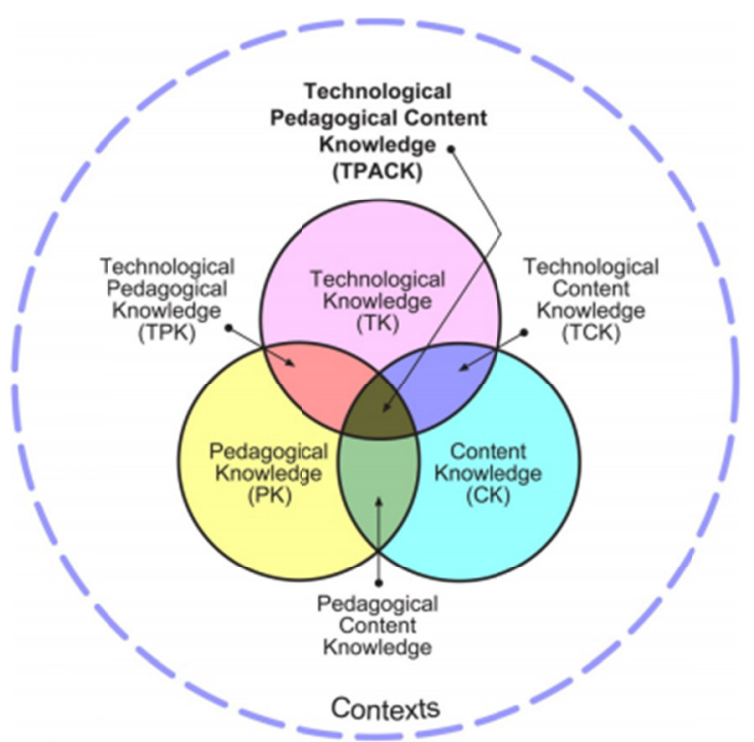

Figure 1. TPACK framework (Mishra \& Koehler, 2006) 
Pedagogical Content Knowledge is the knowledge of pedagogy that is particularly suited to a specific content area (Cox \& Graham, 2009; Koehler \& Mishra, 2009). A preservice teacher might demonstrate this by planning to engage her students in literature discussion groups (Pedagogical Knowledge) to facilitate their understanding of the main ideas in a story (Content Knowledge).

Technological Content Knowledge represents the "knowledge of how to represent concepts with technology" (Cox \& Graham, 2009, p. 64). A preservice teacher might demonstrate this by planning to use an iPad app like Popplet (https://popplet.com) (Technological Knowledge) to represent the main ideas and details in a story as a structured graphic organizer (Content Knowledge).

Technological Pedagogical Knowledge is "an understanding of how teaching and learning can change when particular technologies are used in particular ways" depending on the context and the purpose of a lesson (Koehler \& Mishra, 2009, p. 65). A preservice teacher might demonstrate this by planning to engage students in cooperative learning (Pedagogical Knowledge) using interactive white boards (Maher, 2012) (Technological Knowledge) in a classroom.

Finally, TPACK simultaneously combines content, pedagogical, and technological knowledge to "develop appropriate, context-specific, strategies and representations" for effective and efficient learning (Koehler, Mishra, \& Yahya, 2007, p. 741). A preservice teacher might demonstrate this by using interactive white boards or an iPad app (Technological Knowledge) during literature discussion groups (Pedagogical Knowledge) to understand the main ideas in a story (Content Knowledge).

While these constructs seem straightforward, researchers have noted the "difficulties with measuring the components due to inconsistent definitions of, and unclear boundaries between, the domains" (Anderson et al., 2017, pp. 102-103; Chai, Koh, \& Tsai, 2013; Cox 2008; Young, Young, \& Hamilton, 2014) and researchers have explored other possibilities concerning how to apply them (e.g., Bibi \& Khan, 2017). Thus, we were intentional about defining the constructs in the context of our study.

\section{TPACK: Empirical Research}

In this focused review, we present findings from the last decade about (1) teachers' demonstrations of TPACK in their lesson planning and teaching practices across content areas (i.e., we did not include self-report survey data about TPACK, as this was beyond our scope), and (2) how TPACK constructs have been applied across content area research studies. The first section provides the empirical context for our study and supports the need to address our research question. The second section informs our research design, as well as the need and significance of using a more theoretically grounded approach to coding in this area of research.

\subsection{Teachers' Demonstrations of TPACK}

Studies of teachers' TPACK that focused on technology integration broadly across subject areas underscored that teachers generally needed to develop Technological Pedagogical Knowledge or Technological Content Knowledge (Boschman et al., 2015; Finger \& Finger, 2013; Graham et al., 2012; Hofer \& Grandgenett, 2012; Liu, 2013). However, studies of teachers TPACK in a particular content area underscored the need for teachers to specifically develop Technological Content Knowledge (Hughes \& Scharber, 2008; Maeng et al., 2013; Ozgun-Koca et al., 2011). For example, Hughes and Scharber (2008) reported a case study of an English teacher who had developed and used Technological Pedagogical Knowledge in her instructional decision making, but not Technological Content Knowledge. Likewise, a case study of a math teacher showed that over time she greatly developed her Technological Pedagogical Knowledge, but her development of Technological Content Knowledge was stagnant (Ozgun-Koca et al., 2011). Similarly, a study of six special education preservice teachers found that they mostly drew on Technological Pedagogical Knowledge or TPACK, and never demonstrated just Technological Content Knowledge (Anderson et al., 2017). Finally, Zhang (2019) reported that inservice foreign language teachers demonstrated that younger teachers showed more Technological Knowledge and Content Knowledge, and older teachers showed more Pedagogical Knowledge. Our study explores whether preservice teachers demonstrate similar or different patterns in their planning of literacy lessons.

Further, one study showed that most science teachers demonstrated TPACK in their lessons when they were (a) intentional about selecting content-specific technologies and (b) took advantage of the functionalities and affordances of these technologies to facilitate students' mastery of content-related objectives (Maeng et al., 2013). They concluded that science teachers should consider "the pedagogical challenges specific to the curriculum, students, and classroom setting, as well as how technology can help to overcome these challenges" (p. 840). Based on this finding, we designed supports for the preservice teachers in our study to select 
content-specific technologies as part of our methodology.

Given the importance of content area specific explorations of teachers' TPACK (Dexter et al., 2006; Sprague, 2004), we find it critical to understand TPACK for teachers in our own field of elementary literacy education. However, most existing studies of literacy elementary preservice and inservice teachers do not discuss whether and how specific constructs of TPACK are evident or absent in their literacy instruction. Studies tend to examine how teachers integrate specific digital text and tool (e.g., iPads, particular apps) in their literacy instruction (Hutchison, Beschorner, \& Schmidt - Crawford, 2012; Hutchison \& Colwell, 2016; Israelson, 2014; Jahnke \& Kumar, 2014; Laster et al., 2016). Other studies provide a broad discussion of different digital tools that teacher educators prepare literacy teachers to use or technological decisions that teachers made to support developmentally appropriate instruction (Boche, 2019; Price-Dennis, Holmes, \& Smith, 2015; Steckel et al., 2015; Voogt \& McKenney, 2017). Another study focused on inservice kindergarten teachers' discussions about designing on- and off-line early literacy PictoPal activities, but lesson plans or implementation were not included as data sources (Boschman et al., 2015). While one study focused on secondary English teachers' TPACK (e.g., Hughes \& Scharber, 2008), secondary English and elementary literacy instruction are distinct both in terms of the stages of literacy development of students, and also in content. For instance, while secondary English teachers may focus on content such as Shakespeare or journalism (Hughes \& Scharber, 2008), elementary literacy teachers focus more on literacy strategy instruction related to word recognition, fluency, vocabulary, comprehension, etcetera. Our study aims to address these gaps in the research by exploring elementary preservice teachers' demonstrations of TPACK specifically in literacy lesson plans.

\subsection{How TPACK Constructs Have Been Applied in Previous Research}

Two challenges to understanding the existing research on teachers' demonstrations of TPACK across content areas are that (1) few studies use the constructs from the TPACK framework to code their data, and (2) when they do so, how the TPACK constructs (Technological Knowledge, Pedagogical Knowledge, Content Knowledge, Technological Pedagogical Knowledge, Technological Content Knowledge, Pedagogical Content Knowledge) are applied varies across studies considerably. For example, some researchers used the TPACK framework to guide their study, but did not apply any of the categories to their data coding (Boche, 2019; Beschorner \& Kruse, 2016; Drajati, Tan, Haryati, Rochsantiningsih, \& Zainnuri, 2018; Hosek, 2018; Hutchison \& Colwell, 2016; Laster et al., 2016; Saudelli \& Ciampa, 2016). Others used narrative, descriptive examples of TPACK without engaging in an explicit coding process (Finger \& Finger, 2013; Hughes \& Scharber, 2008; Liu, 2013; Maeng et al., 2013; Steckel et al., 2015). While these data coding approaches provide some important and relevant information to the field, not using systematic coding that directly aligns with the TPACK theory has drawbacks for trying to draw empirical conclusions.

We found only eight previous studies, across content areas, which used the TPACK constructs in some way to code their data. Maeng and colleagues (2013) only coded TPACK as the sole coded construct, not any of its subconstructs, in their evaluations of science preservice teachers. Graham and colleagues (2012) used open coding to identify categories for elementary preservice teachers' written rationales for their lesson plans, and then mapped those codes onto selected constructs from TPACK (Technological Knowledge, Technological Pedagogical Knowledge, and TPACK). Ozgun-Koca and colleagues (2011) coded math preservice teachers' demonstrations of selected TPACK constructs (Pedagogical Content Knowledge, Technological Content Knowledge, and Technological Pedagogical Knowledge). Likewise, Hofer and Grandgenett (2012) coded preservice teachers' demonstrations of only three aspects of their TPACK (i.e., Technological Pedagogical Knowledge, Technological Content Knowledge, and TPACK) across different content area lesson plans and reflections. Zhang (2019) coded inservice foreign language teachers' demonstrations of four TPACK constructs (Content Knowledge, Technological Knowledge, Pedagogical Content Knowledge, and Technological Pedagogical Knowledge). Similarly, Wang (2016) coded preservice teachers' demonstrations of four TPACK constructs (Pedagogical Knowledge, Content Knowledge, Pedagogical Content Knowledge, and Technological Knowledge) based on their presentations about how they might use digital storytelling in their foreign language instruction. In contrast, Boschman and colleagues (2015) applied all possible TPACK constructs (Technological Knowledge, Content Knowledge, Pedagogical Knowledge, Pedagogical Content Knowledge, Technological Content Knowledge Technological Pedagogical Knowledge, and TPACK) to code teachers' discussions about PictoPal activity designs. Likewise, Anderson and colleagues (2017) also coded special education preservice teachers' TPACK dimensions for each instructional decision using all possible TPACK constructs. In our study, we also coded our data using TPACK constructs. Our review of the literature suggested that teachers' demonstrations of need for further TPACK development were typically related to combining kinds of TPACK knowledge. Thus, we focused our coding on the constructs that demonstrate combinations of knowledge (i.e., 
Pedagogical Content Knowledge, Technological Content Knowledge, Technological Pedagogical Knowledge, and TPACK).

\section{Methods}

This study uses a qualitative directed content analysis approach (Hsieh \& Shannon, 2005). We chose this method for three reasons. First, it allowed us to (a) use the TPACK theoretical constructs as our starting point for coding, but also (b) continue to define codes ourselves during data analysis. Second, related to this, it allowed us to "validate or extend" the TPACK theoretical framework by identify "categories [that] either offer a contradictory view of the phenomenon or might further refine, extend, and enrich the theory" (Hsieh \& Shannon, 2005, p. 1281, 1283). Finally, this process allowed us to present "codes with exemplars and offer descriptive evidence" of our findings (Hsieh \& Shannon, 2005, p. 1282). These affordances fit well with our research goal.

\subsection{Participants}

Participants included 45 preservice teachers who were taking literacy teaching methods service-learning courses. Of these, five were males and 40 females. Two students were African-American, one was Middle Eastern, one was Slovakian, and 41 were Caucasian. Two students were in their forties, and 43 were in their twenties. Every participant was a junior in college and taking their last of three literacy methods courses before student teaching.

\subsection{Setting and Course Description}

The second author had an ongoing partnership with a community center, in which she embedded her undergraduate literacy methods courses. As part of this partnership, preservice teachers and the second author met at the community center across all 15-weeks of the course and preservice teachers worked with a K-6 child across 10 one-hour sessions during the semester. During these sessions, the second author supervised, coached, and provided feedback. Four of the sessions focused on literacy assessment, and six focused on providing assessment-based instruction. Across the six lessons focused on assessment-based instruction, preservice teachers were expected to include digital texts or tools to transform their students' learning in one or more lessons (see Baxa \& Christ, 2018; Puentedura, 2010). This study focuses of the lesson plans that preservice teachers wrote for the six weeks of the course during which they provided assessment-based literacy instruction, and particularly on those lessons plans in which they integrated the use of digital texts or tools.

Three methods were used to support preservice teachers' integration of digital texts and tools in literacy instruction. First, the professor (second author) included readings that presented digital texts or tools and their integration in instruction as models of practices (e.g., Bromley et al., 2014; Cahill \& McGill - Franzen, 2013; Dalton, 2014; Dalton \& Grisham, 2011; Fisher \& Frey, 2015; Hutchison et al., 2012; Hutchison \& Woodward, 2014; Javorsky \& Trainin, 2014; Kingsley \& Tancock, 2014). After reading each article, preservice teachers completed a reader response template that was then used for reference when each reading was discussed as a whole group in class. Discussions were facilitated by the professor, and often provided an opportunity to correct misconceptions about integrating digital texts and tools.

Second, the professor (second author) provided feedback on preservice teachers' lesson plans that integrated digital texts and tools. Often this feedback was in the form of a question to prompt a student's deeper thinking - e.g., "Does the online text provide the word when you click on it? Is that how it helps with sight words?" or "You say that you are going to use a YouTube video. How does the video better support teaching the content than if you read the book?" Occasionally, feedback was more directive-e.g., "Modeling the Doodle Buddy features is important, and a great way to start. Also, model creating an imaginary friend and writing your narrative in Doodle Buddy (just like you want the student to do next)."

Third, preservice teachers engaged in peer reflective discussions after each lesson. During these, preservice teachers (and sometimes the professor) provided feedback in the form of suggestions for improving integration of digital texts and tools in their literacy teaching practices.

\subsection{Data Sources}

Across preservice teachers' coursework, there were 95 lesson plans in which they planned to use digital texts or tools as part of their literacy instruction. These were the sole data source for our study. In each lesson plan, preservice teachers identified materials, teaching methods that included a step-by-step description of teaching, and a plan for assessing whether or not the child met the objective (usually through observations during the lesson).

\subsection{Data Coding and Analysis}

We jointly discussed and applied a priori codes that stemmed from the combined constructs represented in the 
TPACK framework (i.e., Technological Pedagogical Knowledge, Technological Content Knowledge, Pedagogical Content Knowledge, and TPACK). Since we had asked the preservice teachers to integrate technology that their student would also use in the lesson, we expected that preservice teachers would not only (a) choose a technology that would support their pedagogy, but also (b) model and guide the child to be able to use the technology appropriately. Our definitions for Technological Pedagogical Knowledge, Technological Content Knowledge, and Pedagogical Content Knowledge are presented in the first three rows of Table 1.

Table 1. Technological Pedagogical and Content Knowledge (TPACK) codes and their definitions

\begin{tabular}{|c|c|}
\hline 1. Code & 2. Definition \\
\hline 1. Pedagogical Content Knowledge & The preservice teacher plans to use pedagogy that effectively addresses specific literacy content. \\
\hline 2. Technological Content Knowledge & $\begin{array}{l}\text { The preservice teacher plans to use technological texts or tools in ways that support the learning } \\
\text { of literacy content. }\end{array}$ \\
\hline $\begin{array}{l}\text { 3. Technological Pedagogical } \\
\text { Knowledge }\end{array}$ & $\begin{array}{l}\text { The preservice teacher plans to select technology has affordances that support her literacy } \\
\text { pedagogy AND she plans to teach students how to use these affordances. }\end{array}$ \\
\hline $\begin{array}{l}\text { 4. Technological Content Knowledge } \\
\text { and Pedagogical Content Knowledge }\end{array}$ & $\begin{array}{l}\text { The preservice teacher plans to use (a) technology in ways that supports the learning of literacy } \\
\text { content (i.e., Technological Content Knowledge) AND (b) pedagogy that effectively addresses } \\
\text { specific literacy content (i.e., Pedagogical Content Knowledge). } \\
\text { However, the teacher does not plan to use a technology that supports her pedagogy and teach } \\
\text { students how to use the affordances of the technology (i.e., Technological Pedagogical } \\
\text { Knowledge). }\end{array}$ \\
\hline $\begin{array}{l}\text { 5. Technological Content Knowledge } \\
\text { and Technological Pedagogical } \\
\text { Knowledge }\end{array}$ & $\begin{array}{l}\text { The preservice teacher plans to (a) use technology in ways that supports the learning of literacy } \\
\text { content (i.e., Technological Content Knowledge) AND (b) use a technology that supports her } \\
\text { pedagogy and teach students how to use the affordances of the technology (i.e., Technological } \\
\text { Pedagogical Knowledge). } \\
\text { However, the teacher does not use pedagogy that effectively addresses specific literacy content } \\
\text { (i.e., Pedagogical Content Knowledge). }\end{array}$ \\
\hline $\begin{array}{l}\text { 6. Pedagogical Content Knowledge and } \\
\text { Technological Pedagogical Knowledge }\end{array}$ & $\begin{array}{l}\text { The preservice teacher plans to (a) use pedagogy that effectively addresses specific literacy } \\
\text { content (i.e., Pedagogical Content Knowledge) AND (b) use a technology that supports pedagogy } \\
\text { and teaches students how to use the affordances of the technology (i.e., Technological } \\
\text { Pedagogical Knowledge). } \\
\text { However, the teacher does not plan to use technology in ways that supports the learning of } \\
\text { literacy content (i.e., Technological Content Knowledge). }\end{array}$ \\
\hline 7. TPACK & $\begin{array}{l}\text { The preservice teacher plans to use (a) pedagogy that effectively addresses specific literacy } \\
\text { content (i.e., Pedagogical Content Knowledge), (b) a technology in ways that supports the } \\
\text { learning of literacy content (i.e., Technological Content Knowledge), and (c) a technology that } \\
\text { supports pedagogy and teach students how to use the affordances of the technology (i.e., } \\
\text { Technological Pedagogical Knowledge). }\end{array}$ \\
\hline
\end{tabular}

Through this process of identifying preservice teachers' demonstrations of combined TPACK constructs (Technological Pedagogical Knowledge, Technological Content Knowledge, Pedagogical Content Knowledge) in their lesson planning, we discovered that sometimes preservice teachers would demonstrate combinations of two combined constructs. For example, a preservice teacher might demonstrate both Technological Content Knowledge and Pedagogical Content Knowledge, but not Technological Pedagogical Knowledge (Figure 2). This suggested to us that just because a preservice teacher demonstrated some technological, pedagogical, and content knowledge, it did not mean that they had truly integrated all of these. Given this, we considered demonstration of all three combinations of combined knowledge (see Table 1, rows 4, 5, and 6) as equivalent to TPACK (see Table 1, row 7). Further, given our discovery of these combinations of combined knowledge, we felt it was important to show how preservice teachers demonstrated these in their literacy lesson planning (i.e., Technological Content Knowledge and Pedagogical Content Knowledge, Technological Content Knowledge and Technological Pedagogical Knowledge, or Pedagogical Content Knowledge and Technological Pedagogical Knowledge). Thus, we included these as distinct codes as well (see Table 1, rows 4-6). Finally, since our focus was on how preservice teachers combined constructs of TPACK knowledge, based on our literature review, we did not code for their demonstrations of just Technological Knowledge, Pedagogical Knowledge, or Content Knowledge alone.

To conclude our qualitative content analysis of these data (Hsieh \& Shannon, 2005) we used two final steps. First, we calculated the total frequency of occurrence for each pattern in our coding system (Table 1). Second, we calculated the percentage of occurrence for each pattern out of the total number of lessons. 


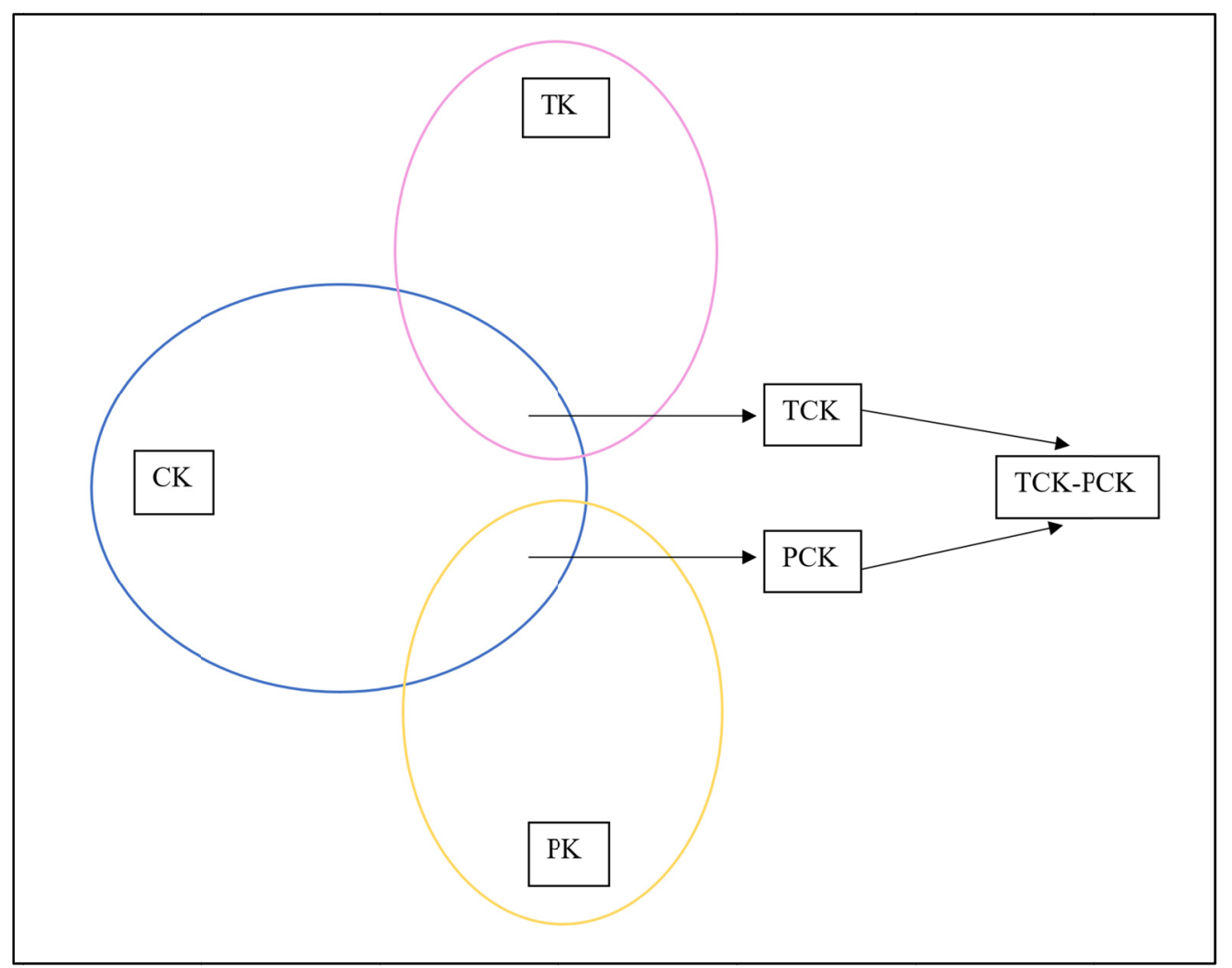

Figure 2. Combined technological content knowledge and pedagogical content knowledge

Note. TK: Technological Knowledge; CK: Content Knowledge; PK: Pedagogical Knowledge; TCK: Technological Content Knowledge; PCK: Pedagogical Content Knowledge; TCK-PCK: Technological Content Knowledge and Pedagogical Content Knowledge.

\section{Findings: Patterns of TPACK Integration}

Preservice teachers demonstrated some combination of TPACK (i.e., Technological Content Knowledge, Technological Pedagogical Knowledge, Pedagogical Content Knowledge, Technological Content Knowledge and Technological Pedagogical Knowledge, Technological Content Knowledge and Pedagogical Content Knowledge, or TPACK) in $98 \%$ of lesson plans. Only $2 \%$ of lessons did not exhibit any combinations of TPACK (i.e., two lessons; see Figure 3). For example, Anna's first lesson focused on developing literacy content knowledge regarding comprehension (all names are pseudonyms). She planned to do this by helping her student identify text features. She decided to use a website that presented a digital book with affordances, such as word hotspots, which read the word aloud when pressed. While these hotspots could have supported word recognition, they did not support her content focus on using text structure to aid comprehension. Thus, her planning did not demonstrate Technological Content Knowledge because even though technology was used (a digital text with hotspots), it did not appropriately support her content objective. Further, she selected a technology that did not have affordances that supported her literacy pedagogy (i.e., hotspots did not support teaching text structure) and she did not plan to teach the student how to use these affordances (i.e., by providing modeling or guided practice. Thus, she did not demonstrate Technological Pedagogical Knowledge. Finally, she demonstrated a lack of Pedagogical Content Knowledge because she planned to tell her student that she would be reading an informational text to teach text structure, when the text selected was actually narrative fiction. Further, her plan to teach the content did not include any modeling or guided practice for using text structure. Also, two patterns never occurred in our dataset: Technological Pedagogical Knowledge, and combined Pedagogical Content Knowledge and Technological Pedagogical Knowledge. Patterns that did occur are discussed in the following subsections. 


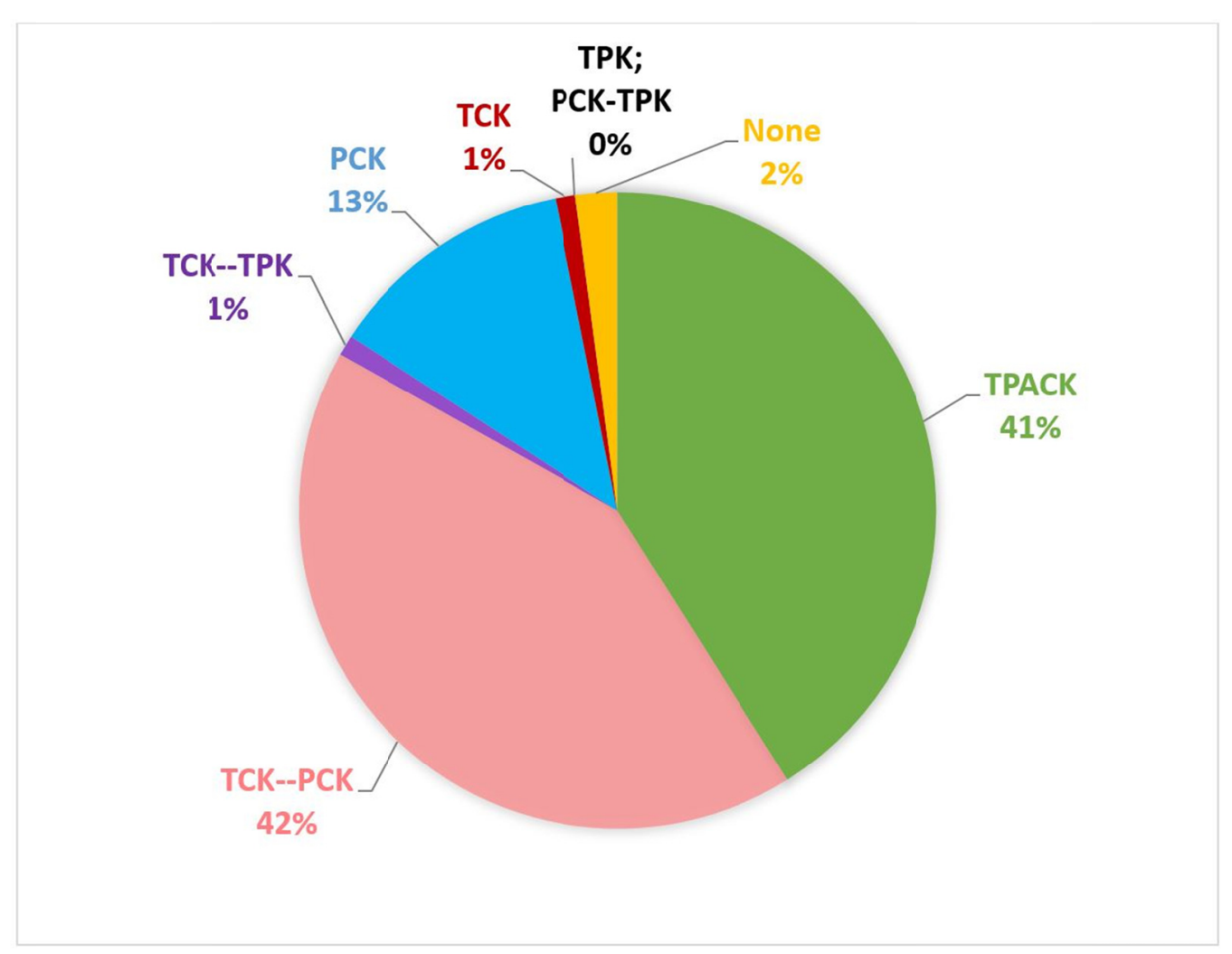

Figure 3. Percentage of preservice teachers' demonstrations of each combination of TPACK constructs across lesson plans

Note. TPK: Technological Pedagogical Knowledge; TCK: Technological Content Knowledge; PCK: Pedagogical Content Knowledge; TCK-TPK: Technological Content Knowledge and Technological Pedagogical Knowledge; TCK-PCK: Technological Content Knowledge and Pedagogical Content Knowledge; PCK-TPK: Pedagogical Content Knowledge and Technological Pedagogical Knowledge; TPACK: Technological Pedagogical Content Knowledge.

\subsection{TPACK}

Preservice teachers showed that they fully integrated TPACK in $41 \%$ of literacy lesson plans by integrating all three possible combinations of combined knowledge (Figure 3). For example, in Maddie's fourth lesson, she planned to teach her student to differentiate the short vs. long /a/ vowel pattern using a word sort app. First, she demonstrated Technological Content Knowledge by selecting an app with affordances that addressed her focal content, recognizing short vs. long /a/ patterns, by reading the words aloud when pressed (i.e., word hotspots). Second, she demonstrated Technological Pedagogical Knowledge by planning to model and guide her student to use the digital affordances (i.e., activating the word hotspots) so the student could listen to the sounds in the word as they were read aloud by the app. Third, she demonstrated Pedagogical Content Knowledge by planning to provide modeling and guided practice for differentiating the long vs. short vowel sounds. In sum, she demonstrated combined Technological Content Knowledge, Technological Pedagogical Knowledge, and Pedagogical Content Knowledge-i.e. TPACK in her planning.

\subsection{Technological Content Knowledge and Pedagogical Content Knowledge}

Preservice teachers demonstrated two combinations-Technological Content Knowledge and Pedagogical Content Knowledge (but not Technological Pedagogical Knowledge) - in 42\% of their literacy lesson plans (Figure 3). Preservice teachers integrated Technological Content Knowledge by choosing digital texts and tools to address several literacy content objectives related to word recognition, comprehension, and writing. For example, Kristin chose the Phonics Awareness app to teach her first-grade students how to identify long from short-vowels in one-syllable words. For each of the vowels, the app provides both a word with a long and short vowel side-by-side. As students click on the vowels in each word, they would hear the sound that the vowel produces. For example, the student would hear that in the word "gate," /a/ is an example of a long vowel because it produces the same name as the letter. The app aligned well with the literacy content objective, and the 
presence of hotspots and sound in this app transform the learning experience. Kristin's decision to use this app thus demonstrated Technological Content Knowledge. Additionally, Kristin planned to model discriminating between long and short vowel patterns and sorting these sounds, and guiding the students to engage in this process as well. Thus, she showed Pedagogical Content Knowledge. However, Kristin did not plan to model or teach her students how to take advantage of the affordances of the app, such as clicking on the hotspots or sorting the information in columns. Thus, she did not demonstrate Technological Pedagogical Knowledge as defined in this study (Table 1). In sum, Kristin demonstrated integration of Technological Content Knowledge and Pedagogical Content Knowledge in this particular lesson, but not Technological Pedagogical Knowledge.

\subsection{Technological Content Knowledge and Technological Pedagogical Knowledge}

Preservice teachers demonstrated two combinations--Technological Content Knowledge and Technological Pedagogical Knowledge - together in only $1 \%$ of the literacy lessons (i.e., one lesson; Figure 3). The lesson in which Technological Content Knowledge and Technological Pedagogical Knowledge was demonstrated was planned by Levonna, who was working with her kindergarten student on letter and sound identification using the Starfall website. This website presented all the uppercase and lowercase letters, and made the letter sounds when students clicked on them. The technology Levonna selected had affordances that supported addressing the literacy content objective, thereby demonstrating Technological Content Knowledge. Additionally, Levonna planned on teaching her student how to click on a letter to see what the uppercase and lowercase versions of the letter look like and click on the arrow next to the letter to hear its sound (Technological Pedagogical Knowledge). However, she did not plan to teach the student the difference between upper- and lower-case letters, or explain that each letter has a name and a sound, thus she did not demonstrate (Pedagogical Content Knowledge). Overall, in this example, Levonna demonstrated deeper understanding of the affordances of the selected technology and the disciplinary content within which it functioned, thereby demonstrating both Technological Content Knowledge and Technological Pedagogical Knowledge, but not Pedagogical Content Knowledge.

\subsection{Pedagogical Content Knowledge}

Preservice teachers demonstrated Pedagogical Content Knowledge in 13\% of the literacy lesson plans (Figure 3). For example, for a second-grade lesson on retelling the main events in a story (literacy content objective about comprehension), David chose a video of the author reading the book I Got the Rhythm. This digital text was not appropriate for retelling because it did not have a clear story line or text structure, thus demonstrating David's lack of Technological Content Knowledge (i.e., the digital affordances did not support the content objective). Despite poor digital text selection, David planned to model using a graphic organizer while reading the first few pages of the story, and then to guide the students to do the same across the rest of the text to facilitate retelling. Thus, David planned to use appropriate pedagogy (i.e., modeling and guided practice) to address literacy content (i.e., retelling/comprehension), thereby demonstrating Pedagogical Content Knowledge. However, because the digital affordances did not support using the graphic organizer for retelling, David did not demonstrate Technological Pedagogical Knowledge in this lesson.

\subsection{Technological Content Knowledge}

Preservice teachers demonstrated Technological Content Knowledge in just 1\% of lesson plans (i.e., one lesson, Figure 3). The lesson in which Technological Content Knowledge was demonstrated focused on writing instruction. Amber planned to teach middle school students about word choice and imagery. She selected a YouTube video of a biography poem by a basketball player, LeBron James, which addressed these aspects of writing. The video provided better opportunities for understanding writers' craft as compared to a paper text. For example, as it read the poem aloud it highlighted the text to draw students' attention to descriptive phrases, such as "unconditional vertigo" and "rough waters of the spotlight". Thus, in this lesson plan, Amber demonstrated Technological Content Knowledge. However, Amber did not plan to use any instruction other than showing the video, so pedagogy was absent from her planning. Thus, she did not demonstrate Technological Pedagogical Knowledge or Pedagogical Content Knowledge.

\section{Discussion and Implications}

In this section, we discus six ways that our study's findings contribute to the existing research by aligning with, diverging from, or extending previous research findings about teachers' demonstrations of TPACK. Integrated in this discussion are also implications for research and practice.

First, the rate of preservice teachers' demonstrations of TPACK in our study (41\%) aligned with the rates of teachers demonstrating TPACK in previous studies that reported such findings (Hughes \& Scharber, 2008; Liu, 2013; Maeng et al., 2013; Ozgun-Koca et al., 2011). By identifying rates of TPACK success for preservice 
teachers' literacy lesson planning, this study extends previous research in English, science, and math. While this is a promising success for literacy teachers across almost half of the lesson plans, it also suggests that literacy teacher educators need to find ways to further increase these successes. The implications that follow the findings throughout this section may provide some ways to try to further support and enhance preservice teachers' TPACK.

Second, our finding that preservice teachers rarely demonstrated Technological Content Knowledge (1\%) also aligned with previous studies that found this similar pattern (e.g., Anderson et al., 2017; Boschman et al., 2015; Hofer \& Grandgenett, 2012; Hughes \& Scharber, 2008; Liu, 2013; Maeng et al., 2013; Ozgun-Koca et al., 2011). This underscores the need to better support teachers to develop Technological Content Knowledge to increase their attainment of TPACK within particular disciplines. One implication might be to consider adopting or developing discipline-specific frameworks to guide planning for technology integration. For example, a newly developed literacy-specific framework, such as the DigiLit Framework (Baxa \& Christ, 2018), might better support literacy preservice teachers' selections of technologies that would fit literacy content objectives by providing four criteria for technology selection for literacy instruction (content accuracy, quality, intuitiveness, and interactivity).

Third, our finding that preservice teachers sometimes demonstrated Pedagogical Content Knowledge (13\%) diverged from the findings of other previous content area studies (Anderson et al., 2017; Hughes \& Scharber, 2008; Maeng et al., 2013; Ozgun-Koca et al., 2011). Preservice teachers in our study may have had better developed Pedagogical Content Knowledge because they had taken three literacy teaching methods courses. Also, these were embedded service-learning courses in which they worked with children on literacy activities weekly across the semester with their professor observing and coaching these sessions. This may highlight the importance of having multiple courses and scaffolded teaching experiences to develop preservice teachers Pedagogical Content Knowledge. For example, teacher education programs could require embedded service-learning teaching methods courses so that preservice teachers have opportunities to practice pedagogies specific to particular content areas to develop their Pedagogical Content Knowledge.

Fourth, preservice teachers in our study did not demonstrate just Technological Pedagogical Knowledge (0\%), which diverges from the findings of previous research that found a high percentage of teachers using just Technological Pedagogical Knowledge (Anderson et al., 2017; Hughes \& Scharber, 2008; Ozgun-Koca et al., 2011; Hofer \& Grandgenett, 2012). Additionally, PTs, rarely demonstrated Technological Content Knowledge and Technological Pedagogical Knowledge together (1\%). How Technological Pedagogical Knowledge is defined and applied in our study might be one reason for these disparate findings. In other studies, when teachers provided rationales for why they used the technologies, they focused on how technology supported pedagogy (Graham et al., 2012). In our study, Technological Pedagogical Knowledge was defined as preservice teachers considering not only the affordances of the technology that supported her literacy pedagogy, but also whether she planned to teach students how to use those affordances. From this perspective, our findings suggest that while teachers may be readily able to use technology in their instruction, they are less readily able to teach children how to use these technologies are part of their lesson. Thus, focusing more on how to teach children to use technologies may be warranted, especially given the evidence that often children do not use technologies effectively without explicit instruction (de Jong \& Bus, 2003, 2004; Lefever-Davis \& Pearman, 2005). Further, as we are increasingly being called to integrate technology use by children in literacy instruction (International Reading Association, 2009; National Council of Teachers of English, 2008; National Governors Association Center for Best Practices \& Council of Chief State School Officers, 2010), it may be important to extend how we evaluate Technological Pedagogical Knowledge to also include whether teachers model and guide children to use these technologies as part of their instruction.

Fifth, our study extends previous research by exploring preservice teachers' TPACK in elementary literacy lesson planning. Prior studies explored how teachers integrated TPACK (a) across disciplines (Boschman et al., 2015; Graham et al., 2012; Hofer \& Grandgenett, 2012), or (b) in other specific disciplines such as English, math, science, special education, or foreign language (Anderson et al., 2017; Hughes \& Scharber, 2008; Maeng et al., 2013; Ozgun-Koca et al., 2011; Zhang, 2019). None of these studies specifically explored preservice teachers' technology integration in elementary literacy lesson plans. This is important to explore because most elementary schools use at least a 90-minute literacy instruction block, which represents a significant portion of instruction time each day. Thus, knowing how preservice teachers, who will be teaching these blocks, are integrating technology in their literacy lessons is important to inform how to improve it.

Sixth, our study extends previous research by exploring new ways that TPACK constructs can be combined. Through our coding process, we discovered that sometimes two sets of combined TPACK constructs are 
demonstrated, but not the third (Figure 2). That is, some aspect of integration is missing when not all possible combinations of TPACK constructs are integrated. This begs consideration of how we define TPACK - is it just any evidence of Technology, Pedagogy, and Content combined, or is it being able to fully integrate these? And if it is being able to fully integrate these, how do we define that? We think that Misha and Kohler's intention aligns with our conception of fully integrating TPACK, as they state "equally important to the model are the interactions between and among these bodies of knowledge, represented as Pedagogical Content Knowledge, Technological Content Knowledge, Technological Pedagogical Knowledge, and TPACK" (Koehler \& Mishra, 2009, p. 62). Given this, we believe our methodology and findings underscore the need to (1) code data using the TPACK constructs in order to understand how the theory is being applied, and (2) (re)consider how full TPACK integration might be defined when coding using these constructs. That is, it may be helpful to look for all combinations of combined knowledge to identify full integration. Further, the information gleaned from this study about defining TPACK constructs could be useful to researchers to guide future research in defining and applying codes to their data.

\section{Limitations and Suggestions for Future Research}

There are four limitations to our study that suggest future research directions. First, this study focused on preservice teachers' planning of literacy instruction, not their implementation of this instruction. Future research should also investigate PTs' actual implementations of literacy lessons using digital texts and tools. Second, our study's data were limited to lesson plans, which made it difficult to interpret why preservice teachers made their instructional decisions. To better understand preservice teachers' planning decisions, interviews or retrospective recall should be used in future research in combination with lesson planning or implementation data. Third, in our study, the technological hardware preservice teachers in this study had access to were predominantly laptops and iPads. Future research might also explore preservice teachers' planning or implementation of digital texts and tools when a broader array of technologies is available. Further, future research might explore how teachers' integration of technology varies based on what kinds of access they have to devices - e.g., students bring their own devices, the classroom has devices, or there are carts with devices shared across the school. Fourth, given the convenience sample of literacy preservice teachers in this study, the findings may not be generalizable to other literacy preservice teachers or other broader educational contexts. Studies with broader samples of literacy preservice teachers from different contexts, and inservice teachers, are warranted.

\section{References}

Anderson, S., Griffith, R., \& Crawford, L. (2017). TPACK in special education: Preservice teacher decision making while integrating iPads into instruction. Contemporary Issues in Technology and Teacher Education, 17(1), 97-127.

Baxa, J. K., \& Christ, T. (2018). The DigiLit framework. Reading Teacher, 71(6), 703-714.

Beschorner, B., \& Kruse, J. (2016). Pre-service teachers' use of a technology integration planning cycle: A case study. International Journal of Education in Mathematics, Science and Technology, 4(4), 258-271. https://doi.org/10.18404/ijemst.73952

Bibi, S., \& Khan, S. H. (2017). TPACK in action: A study of a teacher educator's thoughts when planning to use ICT. Australasian Journal of Educational Technology, 33(4), 70-87. https://doi.org/10.14742/ajet.3071

Boche, B. (2019). A critical analysis of technology's impact on teacher's views of literacy learning and teaching: A continuum of understandings. Journal of Literacy and Technology, 20(4), 46-80.

Boschman, F., McKenney, S., \& Voogt, J. (2015). Exploring teachers' use of TPACK in design talk: The collaborative design of technology-rich early literacy activities. Computers \& Education, 82, 250-262. https://doi.org/10.1016/j.compedu.2014.11.010

Bromley, K., Faughnan, M., Ham, S., Miller, M., Armstrong, T., Crandell, C., ... Marrone, N. (2014). Literature circles go digital. The Reading Teacher, 68(3), 229-236. https://doi.org/10.1002/trtr.1312

Cahill, M., \& McGill - Franzen, A. (2013). Selecting "app" ealing and "app" ropriate book apps for beginning readers. The Reading Teacher, 67(1), 30-39. https://doi.org/10.1002/TRTR.1190

Center for Educational Leadership. (2019). 5 Dimensions of Teaching and Learning Framework. Retrieved from https://www.k-12leadership.org/content/tool/5-dimensions-teaching-and-learning\%E2\%84\%A2

Chai, C.-S., Koh, J. H.-L., \& Tsai, C.-C. (2013). A Review of Technological Pedagogical Content Knowledge. Educational Technology \& Society, 16(2), 31-51.

Cox, S. (2008). A conceptual analysis of technological pedagogical content knowledge. Unpublished doctoral 
dissertation. Provo, UT: Brigham Young University.

Cox, S., \& Graham, C. R. (2009). Using an elaborated model of the TPACK framework to analyze and depict teacher knowledge. TechTrends, 53(5), 60-69. https://doi.org/10.1007/s11528-009-0327-1

Dalton, B. (2014). Level up with multimodal composition in social studies. The Reading Teacher, 68(4), 296-302. https://doi.org/10.1002/trtr.1319

Dalton, B., \& Grisham, D. L. (2011). eVoc strategies: 10 ways to use technology to build vocabulary. The Reading Teacher, 64(5), 306-317. https://doi.org/10.1598/RT.64.5.1

Danielson Group. (2020). Danielson Framework for Teaching. Retrieved from https://danielsongroup.org/framework

de Jong, M. T., \& Bus, A. G. (2003). How well suited are electronic books to supporting literacy? Journal of Early Childhood Literacy, 3(2), 147-164. https://doi.org/10.1177/14687984030032002

de Jong, M. T., \& Bus, A. G. (2004). The efficacy of electronic books in fostering kindergarten children's emergent story understanding. Reading Research Quarterly, 39(4), 348-393. https://doi.org/10.1598/RRQ.39.4.2

Dexter, S., Doering, A. H., \& Riedel, E. S. (2006). Content area specific technology integration: A model for educating teachers. Journal of Technology and Teacher Education, 14(2), 325-345.

Drajati, N. A., Tan, L., Haryati, S., Rochsantiningsih, D., \& Zainnuri, H. (2018). Investigating English language teachers in developing TPACK and multimodal literacy. Indonesian Journal of Applied Linguistics, 7(3), 575-582. https://doi.org/10.17509/ijal.v7i3.9806

Finger, G., \& Finger, P. (2013). Understanding TPACK in Practice: Praxis through Technological Pedagogical Reasoning. International Association for Development of the Information Society.

Fisher, D., \& Frey, N. (2015). Checking for understanding digitally during content area learning. The Reading Teacher, 69(3), 281-286. https://doi.org/10.1002/trtr.1407

Graham, C. R., Borup, J., \& Smith, N. B. (2012). Using TPACK as a framework to understand teacher candidates' technology integration decisions. Journal of Computer Assisted Learning, 28(6), 530-546. https://doi.org/10.1111/j.1365-2729.2011.00472.x

Hsieh, H. F., \& Shannon, S. E. (2005). Three approaches to qualitative content analysis. Qualitative Health Research, 15(9), 1277-1288. https://doi.org/10.1177/1049732305276687

Hofer, M., \& Grandgenett, N. (2012). TPACK development in teacher education: A longitudinal study of preservice teachers in a secondary MA Ed. program. Journal of Research on Technology in Education, 45(1), 83-106. https://doi.org/10.1080/15391523.2012.10782598

Hosek, V. A. (2018). Locating the Critical Component in Technological Pedagogical and Content Knowledge (TPACK): An Examination of How Graduate Students Recruit TPACK and Critical Digital Literacy into Classroom Practices. Doctoral dissertation, Illinois State University. Retreived from https://ir.library.illinoisstate.edu/etd/1011

Hughes, J. E., \& Scharber, C. M. (2008). Leveraging the development of English TPCK within the deictic nature of literacy. In AACTE Committee on Innovation and Technology (Eds.), Handbook of technological pedagogical content knowledge (TPCK) for educators (pp. 87-106). New York, NY: Routledge.

Hutchison, A., Beschorner, B., \& Schmidt - Crawford, D. (2012). Exploring the use of the iPad for literacy learning. The Reading Teacher, 66(1), 15-23. https://doi.org/10.1002/TRTR.01090

Hutchison, A., \& Colwell, J. (2016). Preservice teachers' use of the technology integration planning cycle to integrate iPads into literacy instruction. Journal of Research on Technology in Education, 48(1), 1-15. https://doi.org/10.1080/15391523.2015.1103146

Hutchison, A., \& Woodward, L. (2014). A planning cycle for integrating digital technology into literacy instruction. The Reading Teacher, 67(6), 455-464. https://doi.org/10.1002/trtr.1225

International Reading Association. (2009). New literacies and 21st-century technologies [Position statement]. Newark, DE: Author. Retrieved from https://www.literacyworldwide.org/docs/default-source/where-we-stand/new-literacies-21st-century-positio n-statement.pdf?sfvrsn=6

Israelson, M. H. (2014). A Study of Teachers' Integration of App Affordances and Early Literacy Best Practices. 
Doctoral dissertation, University of Minnesota.

Jahnke, I., \& Kumar, S. (2014). Digital didactical designs: Teachers' integration of iPads for learning-centered processes. Journal of Digital Learning in Teacher Education, 30(3), 81-88. https://doi.org/10.1080/21532974.2014.891876

Javorsky, K., \& Trainin, G. (2014). Teaching young readers to navigate a digital story when rules keep changing. The Reading Teacher, 67(8), 606-618. https://doi.org/10.1002/trtr.1259

Kingsley, T., \& Tancock, S. (2014). Internet inquiry. The Reading Teacher, 67(5), 389-399. https://doi.org/10.1002/trtr.1223

Koehler, M. J., \& Mishra, P. (2009). What is technological pedagogical content knowledge (TPACK)? Contemporary Issues in Technology and Teacher Education, 9(1), 60-70.

Koehler, M. J., Mishra, P., \& Yahya, K. (2007). Tracing the development of teacher knowledge in a design seminar: Integrating content, pedagogy and technology. Computers \& Education, 49(3), 740-762. https://doi.org/10.1016/j.compedu.2005.11.012

Laster, B., Tysseling, L., Stinnett, M., Wilson, J., Cherner, T., Curwen, M., ... Huggins, S. (2016). Effective use of tablets (iPads) for multimodal literacy learning: What we learn from reading clinics/literacy labs. The App Teacher Journal, 1(1). from http://appedreview.com/blog/effective-use-tablets-ipads-multimodal-literacy-learning-learn-reading-clinicsl iteracy-labs/

Lefever-Davis, S., \& Pearman, C. (2005). Early readers and electronic texts: CD-ROM storybook features that influence reading behaviors. The Reading Teacher, 58(5), 446-454.

Liu, S. H. (2013). Exploring the instructional strategies of elementary school teachers when developing technological, pedagogical, and content knowledge via a collaborative professional development program. International Education Studies, 6(11), 58-68. https://doi.org/10.5539/ies.v6n11p58

Maeng, J. L., Mulvey, B. K., Smetana, L. K., \& Bell, R. L. (2013). Preservice teachers' TPACK: Using technology to support inquiry instruction. Journal of Science Education and Technology, 22(6), 838-857. https://doi.org/10.1007/s10956-013-9434-z

Maher, D. (2012). Teaching literacy in primary schools using an interactive whole-class technology: Facilitating student-to-student whole-class dialogic interactions. Technology, Pedagogy and Education, 21(1), 137-152. https://doi.org/10.1080/1475939X.2012.659888

Mishra, P., \& Koehler, M. J. (2006). Technological pedagogical content knowledge: A framework for teacher knowledge. Teachers College Record, 108(6), 1017.

National Council of Teachers of English. (2008). 21st century literacies [Policy Research Brief]. Urbana, IL: Author. Retrieved from https://secure.ncte.org/library/NCTEFiles/Resources/Positions/Chron1107ResearchBrief.pdf?_ga=2.135088 690.2008924364.1591716792-1444659440.1572387337

National Governors Association Center for Best Practices \& Council of Chief State School Officers. (2010). Common Core State Standards for English language arts and literacy in history/social studies, science, and technical subjects. Washington, DC: Authors.

Niess, M. L. (2009). Mathematics Teacher TPACK Standards and Revising Teacher Preparation. In L. Paditz \& A. Rogerson (Eds.), 10th International conference "Models in Developing Mathematics Education" (pp. 445-449). Dresden. Retrieved

from http://math.unipa.it/ grim/21_project/21Project_dresden_sept_2009.htm

Özgün - Koca, S. A., Meagher, M., \& Edwards, M. T. (2011). A teacher's journey with a new generation handheld: Decisions, struggles, and accomplishments. School Science and Mathematics, 111(5), 209-224. https://doi.org/10.1111/j.1949-8594.2011.00080.x

Popplet. (2013). Retrieved from https://popplet.com

Price - Dennis, D., Holmes, K. A., \& Smith, E. (2015). Exploring digital literacy practices in an inclusive classroom. The Reading Teacher, 69(2), 195-205. https://doi.org/10.1002/trtr.1398

Puentedura, R. R. (2010). SAMR and TPCK: Intro to advanced practice. Retrieved from http://hippasus.com/resources/sweden2010/SAMR_TPCK_IntroToAdvancedPractice.pdf 
Saudelli, M. G., \& Ciampa, K. (2016). Exploring the role of TPACK and teacher self-efficacy: an ethnographic case study of three iPad language arts classes. Technology, Pedagogy, and Education, 25(2), 227-247. https://doi.org/10.1080/1475939X.2014.979865

Sprague, D. (2004). Technology and teacher education: Are we talking to ourselves. Contemporary Issues in Technology and Teacher Education, 3(4), 353-361.

Steckel, B., Shinas, V. H., \& Vaerenewyck, L. V. (2015). Artistic technology integration: Stories from primary and elementary classrooms. The Reading Teacher, 69(1), 1-49. https://doi.org/10.1002/trtr.1356

Thompson, A. D., \& Mishra, P. (2007-2008). Breaking news: TPCK becomes TPACK! Journal of Computing in Teacher Education, 24(2), 38.

Voogt, J., \& McKenney, S. (2017). TPACK in teacher education: Are we preparing teachers to use technology for early literacy? Technology, Pedagogy, and Education, 26(1), 69-83. https://doi.org/10.1080/1475939X.2016.1174730

Wang, A. Y. (2016). The impact of digital storytelling on the development of TPACK among student teachers in Taiwan. In M. C. Herring, M. J. Koehler \& P. Mishra (Eds.), The handbook of technological pedagogical content knowledge (TPACK) for educators (pp. 297-308).

Young, J. R., Young, J. L., \& Hamilton, C. (2014). The use of confidence intervals as a meta-analytic lens to summarize the effects of teacher education technology courses on preservice teacher TPACK. Journal of Research on Technology in Education, 46(2), 149-172. https://doi.org/10.1080/15391523.2013.10782617

Zhang, Q. (2019). Technology Enhanced Instruction and English Teacher's TPACK. DEStech Transactions on Social Science, Education and Human Science. International Symposium on Education and Humanities Sciences. https://doi.org/10.12783/dtssehs/isehs2019/31601

\section{Copyrights}

Copyright for this article is retained by the author, with first publication rights granted to the journal.

This is an open-access article distributed under the terms and conditions of the Creative Commons Attribution license (http://creativecommons.org/licenses/by/4.0/). 